\title{
Effect of parity segregation on Mycoplasma hyopneumoniae infection dynamics and pneumonic lesions in pigs
}

\author{
Ricardo Augusto Neves Forner ${ }^{1}$ (i) Karine Ludwig Takeuti ${ }^{1}$ (D) Elisa Rigo De Conti ${ }^{1}$ (i) \\ Monica Santi ${ }^{2}$ Fernando Pandolfo Bortolozzo ${ }^{1}$ (i) David Emilio Santos Neves de Barcellos ${ }^{1^{*}}$ ([)
}

${ }^{1}$ Setor de Suínos, Faculdade de Veterinária, Universidade Federal do Rio Grande do Sul (UFRGS), 91540-000, Porto Alegre, RS, Brasil. E-mail: davidbarcellos@terra.com.br. "Corresponding author.

${ }^{2}$ Master Agroindustrial, Videira, SC, Brasil.

\begin{abstract}
Gilts represent a group risk for Mycoplasma hyopneumoniae vertical transmission in swine herds. Therefore, parity segregation can be an alternative to control M. hyopneumoniae infections. The study evaluated the effect of parity segregation on M. hyopneumoniae infection dynamics and occurrence and severity of lung lesions at slaughter. For that, three multiple site herds were included in the study. Herd A consisted of the farm where gilts would have their first farrowing (parity order (PO) 1). After the first farrowing PO 1 sows were transferred to herd B (PO2-6). Herd $C$ was a conventional herd with gilt replacement (PO1-6). Piglets born in each herd were raised in separated nursery and finishing units. Sows $(n=33(A), 37(B), 34(C))$ in all herds were sampled prior to farrowing and piglets $(n=54(A), 71(B), 66(C))$ were sampled longitudinally at 21,63, 100, 140 days of age and at slaughter for M. hyopneumoniae detection by PCR and lung lesions scoring. M. hyopneumoniae prevalence in sows did not differ among herds. Prevalence of positive piglets was higher at weaning in the PO1 herd (A) ( $P$ $<0.05)$. However, prevalence of positive pigs from 100 days of age to slaughter age was higher in the PO2-6 herd (B) (P < 0.05). Lung lesion occurrence and severity were higher in herd B. The authors suggested that the lack of a proper gilt acclimation might have influenced the results, leading to sows being detected positive at farrowing, regardless of the parity.

Key words: enzootic pneumonia, gilts, lung lesions, parity order, sow farm.
\end{abstract}

Efeito da ordem de parto segregada sobre a dinâmica de infecção de Mycoplasma hyopneumoniae e lesões pulmonares ao abate

RESUMO: As leitoas consistem em um grupo de risco na transmissão vertical de Mycoplasma hyopneumoniae dentro do sistema de produção de suínos. Dessa forma, a segregação de partos poderia ser utilizada como alternativa para controlar as infecções por M. hyopneumoniae. $O$ objetivo deste estudo foi avaliar o efeito da segregação de partos sobre a dinâmica de infecção de M. hyopneumoniae e a ocorrência e severidade das lesões pulmonares a abate. Para isso três sistemas de produção de suínos com três sítios cada foram incluídos no estudo. A granja A consistia da unidade onde as leitoas tem o primeiro parto, ou seja, alojava somente de fêmeas de ordem de parto 1 (Granja OP1). Após o primeiro parto as fêmeas OP1 foram transferidas para a granja B (Granja OP2-6), ou seja, consistia de fêmeas de ordem de parto 2 a 6 , e a granja C consistiu em uma granja convencional com reposição de leitoas (Granja OP1-6), com fêmeas de ordem de parto 1 a 6. Os leitões nascidos de cada granja foram transferidos e criados em creches e terminações segregadas. As matrizes ( $n=33(A), 37(B), 34(C))$ de todas as granjas do estudo foram amostradas previamente ao parto e os leitões $(n=54(A), 71(B), 66(C))$ foram amostrados longitudinalmente aos 21, 63, 100 e 140 dias de idade e ao abate. Em todos os momentos de coleta, as amostras foram avaliadas por PCR para detecção de M. hyopneumoniae. As lesões pulmonares foram avaliadas e escores de lesão foram atribuídos ao abate. A prevalência de matrizes positivas para $M$. hyopneumoniae não diferiu entre as granjas $(P>0,05)$. A prevalência ao desmame foi maior na granja $A(O P 1)(P<0,05)$. No entanto, dos 100 dias de idade até o abate a prevalência de leitões positivos para M. hyopneumoniae foi maior na granja $B(O P 2-6)(P<0,05)$. A ocorrência e severidade de lesões pulmonares foram maiores na granja B. Os autores sugerem que a falta de uma aclimatação adequada das leitoas pode ter influenciado nos resultados, levando à detecção de matrizes positivas ao parto, independente da ordem de parto.

Palavras-chave: pneumonia enzoótica, leitoas, lesões pulmonares, ordem de parição, unidade produtora de leitões.

\section{INTRODUCTION}

Mycoplasma (M.) hyopneumoniae is the primary causative agent of enzootic pneumonia in pigs. It is considered an important primary pathogen in the porcine respiratory disease complex (PRDC), along with some viral and other bacterial pathogens causing significant economic impacts to the swine industry worldwide (MAES et al., 2018). The clinical disease caused by M. hyopneumoniae is characterized by dry, non-productive coughing, decreased daily weight gain and reduced feed efficiency (SIBILA et al., 2009). 
Transmission of $M$. hyopneumoniae within a herd can occur horizontally, from infected to naïve pigs, or vertically from sows to their progeny, by direct or indirect contact during farrowing (FANO et al., 2005; SIBILA et al., 2006). Even though piglets are born free of $M$. hyopneumoniae, a variable number of them can be detected positive at weaning (FANO et al., 2007; NATHUES et al., 2013), since shedding of $M$. hyopneumoniae by the sows during the lactation period significantly influences the probability of piglet colonization at weaning (PIETERS et al., 2014). Moreover, dam parity order (PO) may also be a risk factor for the infection of the offspring by $M$. hyopneumoniae at weaning as young parity sows are more likely to transmit $M$. hyopneumoniae to their offspring (FANO et al., 2006).

Approximately $50 \%$ of gilts are introduced in pig farms each year in order to replace culled sows, increasing the importance of gilts in $M$. hyopneumoniae transmission (ENGBLOM et al., 2007). High replacement rates increase the occurrence of the disease (NATHUES et al., 2013) and the strain variability within the herd (VRANCKX et al., 2011). Recent studies (TAKEUTI et al., 2017a) demonstrated that up to $15.7 \%$ of replacement gilts can be detected positive by PCR at first farrowing, and subpopulations of negative sows can be detected at the first farrowing in positive herds, making them susceptible in subsequent parities (TAKEUTI et al., 2017b). For that purpose, a proper acclimation strategy should be adopted, allowing enough period for gilts to become infected, recover and stop shedding the bacterium by the time of parturition (PIETERS \& FANO, 2016). Since infection can last up to 214 days (PIETERS et al., 2009), acclimation should start at 50 days of age (PIETERS \& FANO, 2016) or as soon as the gilts enter the herd. However, this management is laborious and physical space to house the young incoming gilts is necessary, making this practice not applicable to some farms.

Parity segregation has been used in swine production as a control measure for several diseases including enzootic pneumonia (MAES et al., 2008). Segregating gilts and their offspring from the multiparous sow herd and their progeny until gilts reach their second gestation allows enough time for gilts to acquire a desirable immune status, reducing the risk of herd destabilization if adequate acclimation is performed (MAES et al., 2008; GADD, 2011). In addition, piglets born to young sows increase the risk of the spread of the disease in the nursery period, which can be countered with parity segregation (BREAN et al., 2016). Parity segregation is reported as a control measure for piglet diarrhea, PRRSv (Porcine Reproductive and Respiratory Syndrome virus) and M. hyopneumoniae infections and reducing medication costs in sow herds without gilts (MOORE, 2005; GADD, 2011). A decrease of the severity of pneumonic lung lesions suggestive of $M$. hyopneumoniae infection in slaughtered pigs has been described with the adoption of parity segregation (MOORE, 2005). Supported by these evidences we hypothesized that parity segregation could reduce the transmission of $M$. hyopneumoniae in the multiparous sow herd offspring. Also, no research has been performed on the infection dynamics of $M$. hyopneumoniae in parity segregated systems. Therefore, this study aimed to evaluate the effect of parity segregation on infection dynamics of $M$. hyopneumoniae, and on occurrence and severity of lung lesions in pigs.

\section{MATERIALS AND METHODS}

Herds

The study was carried out on three production systems (A, B and C) with three sites (farrowing unit, nursery and finishing unit) each, being each farrowing unit the only source of piglets to their respective downstream flow, all located in the midwestern region of Santa Catarina State, in the southern region of Brazil. The study was carried out simultaneously in all farms between January and August 2019.

All replacement gilts (PIC Camborough ${ }^{\circledR}$ ) were raised in a multiplier farm positive for $M$. hyopneumoniae and PRRSv negative up to 63 days of age (doa), then moved and housed in a finishing unit up to 180 doa. After that, gilts were moved to a gilt development unit (GDU) where they were vaccinated against reproductive diseases (Eryseng Parvo Lepto ${ }^{\circledR}$, Hipra, Girona, Spain) and atrophic rhinitis (Porcilis ART $^{\circledR}$, MSD Saúde Animal, Brazil) and inseminated. No controlled exposure to $M$. hyopneumoniae was performed during this period. From the GDU, gilts were transported either to farrowing unit $\mathrm{A}$ on a weekly basis, or farrowing unit $\mathrm{C}$ on a monthly basis at approximately 35-60 days of gestation. In farrowing unit $\mathrm{A}$, gilts had their first farrowing and after lactation they were inseminated and transferred to farrowing unit B at 35-45 days of gestation on a weekly basis. Annual replacement rates in herds B and $\mathrm{C}$ were $60 \%$ and $50 \%$, respectively. Lactation length was 21 days in average in all farrowing units. Litters from each farrowing unit were transferred to a separate nursery at 21 doa, and to a finishing unit at 
63 doa. The age of slaughtered pigs ranged from 174184 days among farms. A summary of herds size and pig flows are shown in figure 1.

All replacement gilts were vaccinated for M. hyopneumoniae (Porcilis PCV Mhyo ${ }^{\circledR}$, MSD Saúde Animal, Brazil) at weaning (21 doa) and at 160 doa, when also received a single tulathromycin (Draxxin ${ }^{\circledR}$, Zoetis, NJ, USA) injection. Upon arrival at the GDU, all gilts received amoxicillin (Farmaxilin 50 Premix $^{\circledR}$, Farmabase Saúde Animal, São Paulo, Brazil) in feed for 10 days. In farrowing unit A, gilts received another M. hyopneumoniae vaccine (Porcilis PCV Mhyo $^{\circledR}$, MSD Saúde Animal, Brazil) dose at 95 days of gestation. Piglets born in all farrowing units were vaccinated for M. hyopneumoniae (IngelvacMycoflex ${ }^{\circledR}$, Boeringher Ingelhein, Ingelhein, Germany) at weaning (21 doa). Antibiotic treatment protocols were similar among all nursery and finishing units, feed and water antibiotics effective against $M$. hyopneumoniae were allowed during the study as part of farm management, but no injectable antibiotics effective against $M$. hyopneumoniae were used throughout the trial. All farrowing units were positive for M. hyopneumoniae and Influenza A virus, but negative for Actinobacillus pleuropneumoniae and PRRSv.

Housing and management conditions were similar among all nursery and finishing units. Pig density was $0,27 \mathrm{~m}^{2} /$ pig and $0,9 \mathrm{~m}^{2} /$ pig in the nursery and finishing units, respectively. Flooring was slatted in nurseries and in finishing units flooring was fully solid. All nurseries and finishing units were naturally ventilated with curtains. Throughout the study there were no clinical signs of enteric disorders.

\section{Study design}

At each farrowing unit, 80 piglets born to 40 sows (two piglets per sow) were randomly selected and ear tagged at birth for the longitudinal study. In farrowing unit $\mathrm{A}$, piglets were selected from primiparous sows, while in farrowing units $\mathrm{B}$ and $\mathrm{C}$ piglets were selected from PO 2-6 and PO 1-6 sows respectively. The removal of piglets from their dams was allowed for cross-fostering; although, the two selected piglets enrolled were kept with their biological dam from birth to weaning and suckled colostrum from the biological dam. Additionally, no piglets were introduced to sows enrolled in the study. Sample size was calculated based on an estimated prevalence of $5 \%$ for farms with more than 1000 animals with a $95 \%$ confidence interval, losses due to culling and mortality were also considered.

Data from dead piglets and pigs which lost the ear tag or which could not be sampled at slaughter were removed from the study in all sampling events.

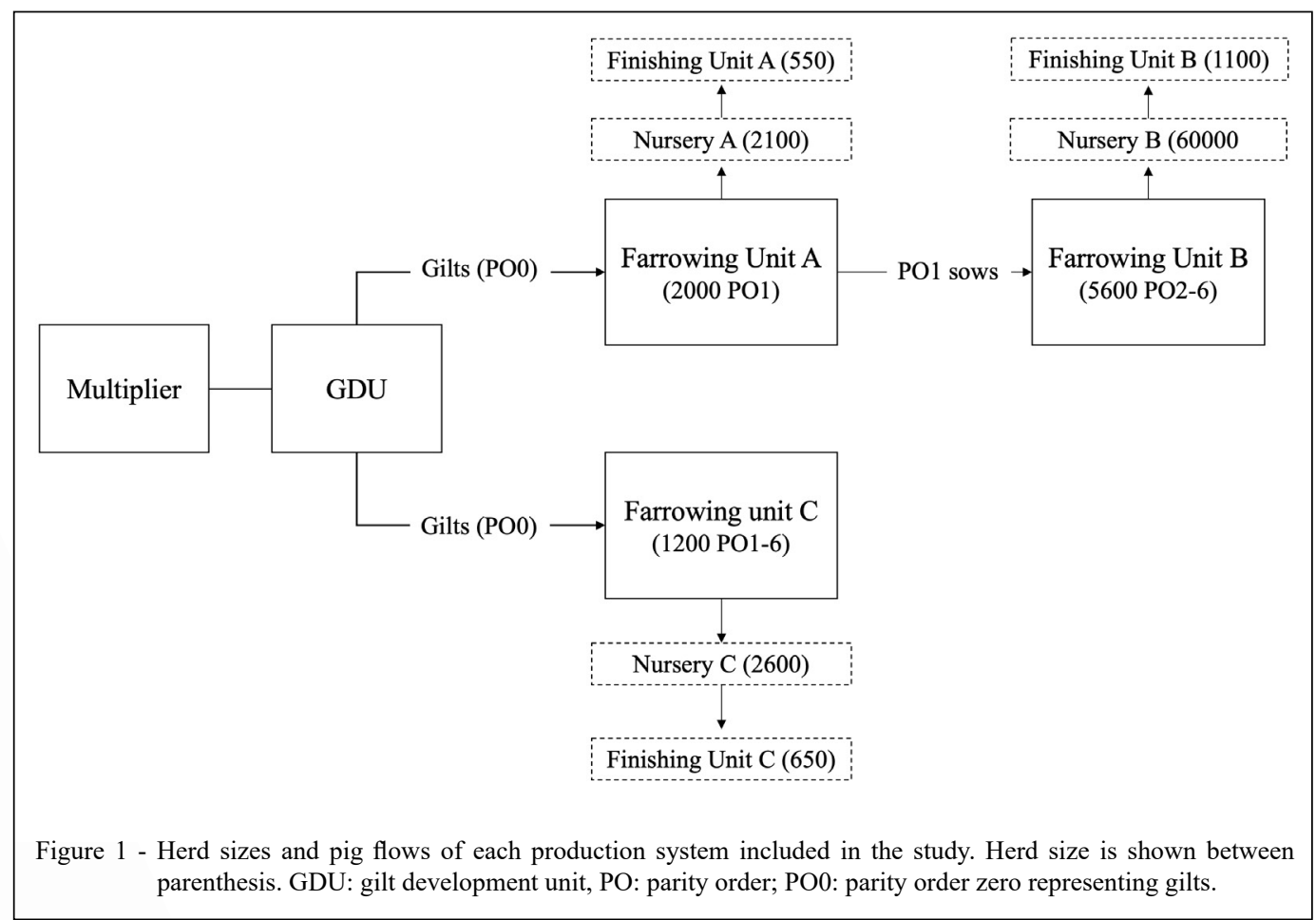

Ciência Rural, v.52, n.2, 2022. 
Sows that had both piglets removed from the study were also excluded. In the end 33 (PO1), 34 (PO2 = $7, \mathrm{PO} 3=11, \mathrm{PO} 4=9, \mathrm{PO} 5=5, \mathrm{PO} 6=6)$ and $37(\mathrm{PO} 1$ $=8, \mathrm{PO} 2=7, \mathrm{PO} 3=7, \mathrm{PO} 4=4, \mathrm{PO} 5=6, \mathrm{PO} 6=2$ ) sows and 54, 71 and 66 pigs were analyzed in herds $\mathrm{A}, \mathrm{B}$ and $\mathrm{C}$, respectively, during the entire study.

\section{Sample collection}

Deep tracheal catheters (DTC) were collected in sows 0-3 days prior to farrowing by inserting a sterile catheter (post cervical cannula for post cervical artificial insemination used in sows, Minitub $^{\circledR}$, Tiefenbach, Germany) through the larynx towards the trachea and rubbing against the tracheal wall, with the aid of a mouth gag, a head flashlight and a laryngoscope (SPONHEIN et al., 2020). Nasal swabs (NS) were collected from piglets at weaning (21 doa) by adding a sterile rayon swab $\left(\mathrm{COPAN}^{\circledR}\right.$, Murrieta, CA, USA) in both nasal cavities and rotating clockwise and counterclockwise, and DTC were collected at 63, 100 and 140 doa. After collection, the tip of the catheter (covered by tracheal mucus) was stored in a sterile conic tube with $0,5 \mathrm{~mL}$ phosphate buffered saline (PBS, Laborclin ${ }^{\circledR}$, Pinhais, Brazil) solution. At slaughter, a fragment from the cranioventral lung lobe was collected from each animal. All samples were identified and refrigerated until storage at -20 ${ }^{\circ} \mathrm{C}$ at the laboratory for further testing.

\section{Lung lesion scoring}

Lungs of all animals were individually assessed for pneumonic lesions (purple to gray colored areas of pulmonary consolidation). Each lung lobe was given a score from 0 to 4 as described by MADEC \& KOBISCH (1982), and the total lung affected area was then calculated considering each lobe relative volume (CHRISTENSEN et al., 1999).

Sample processing and Mycoplasma hyopneumoniae detection by real-time PCR

Nasal swabs, DTC samples and lung fragments were processed for DNA extraction with PureLink $^{\mathrm{TM}}$ Genomic DNA Mini Kit (Thermo Fisher Scientific ${ }^{\circledR}$, Waltham, USA) according to the manufacturer instructions. Real time PCR was performed as described by TAKEUTI et al. (2017a). Reactions were performed in duplicate in a StepOnePlus ${ }^{\mathrm{TM}}$ Real Time thermocycler (Applied Biosystems $^{\circledR}$, Foster City, USA) and two positive and two negative controls were added to each plate. Samples were considered positive for $M$. hyopneumoniae when cycle threshold $(\mathrm{Ct})$ values were $\leq 39.5$.

\section{Statistical analysis}

The M. hyopneumoniae prevalence was estimated at each sampling moment based on the number of positive pigs for M. hyopneumoniae by real-time PCR over the total number of animals sampled in each herd. Multiple pairwise comparison tests of proportions with Bonferroni correction were performed in R v3.2 (The R Foundation for Statistical Computing, Vienna, Austria) to compare the prevalence of $M$. hyopneumoniae by real-time PCR among herds at the same sampling moment. Lung lesion scoring data were analyzed by analysis of variance. Statistical significance was considered when $\mathrm{p}$-values were less than 0.05 .

\section{RESULTS}

The distribution of parity order of sampled sows and the prevalence of $M$. hyopneumoniae positive sows by PCR in each farrowing unit are represented in table 1 . No significant difference $(\mathrm{P}>$ $0.05)$ was found in $M$. hyopneumoniae sow prevalence among herds prior to farrowing (A: $6.1 \% ; \mathrm{B}: 10.8 \%$ and $\mathrm{C}: 8.8 \%$ ).

The detection of $M$. hyopneumoniae in piglets by PCR at all sampling events are shown in figure 2. The prevalence at weaning (21 doa) was statistically different $(\mathrm{P}<0.05)$ between herds A $(20.4 \%)$ and B (4.2\%), and between herds A and C (7.6\%); although, no differences were reported between herds B and C. Detection of positive piglets decreased at the end of the nursery period (63 doa) and no significant differences were found among herds (A: $1.8 \%$; B: $0.0 \%$ and C: $0.0 \%$; P > 0.05). On the other hand, at 100 doa the prevalence of positive pigs was significantly higher $(\mathrm{P}<0.05)$ in herd $\mathrm{B}$ $(15.5 \%)$ when compared to herds $\mathrm{A}(1.8 \%)$ and $\mathrm{C}$ $(0.0 \%)$. At 140 doa the prevalence increased in herd $\mathrm{B}(71.8 \%)$ being significant higher $(\mathrm{P}<0.05)$ when compared to herds $\mathrm{A}(0.0 \%)$ and $\mathrm{C}(1.5 \%)$ which remained low. In the same way, the percentage of $M$. hyopneumoniae positive lungs at slaughter age was significantly higher $(\mathrm{P}<0.05)$ in herd $\mathrm{B}(\mathrm{A}: 27.8 \%$; B: $78.9 \%$ and C: $33.3 \%$ ). A total of $3.7 \%$ of piglets from all herds born to positive sows were detected positive at weaning. In herd $\mathrm{B}, 1.4 \%$ of positive piglets were born to PO2 sows, $1.4 \%$ to PO4 sows and $1.4 \%$ to PO5 sows. In herd C $3.0 \%$ were born to PO1 sows, $3.0 \%$ to PO5 sows and $1.5 \%$ to PO6 sows.

Not all lungs could be assessed for lesions scoring due to losses of lung lobes caused by pleurisy adherences. In addition, some animals were slaughtered separately due to other health issues, 
Table 1 - Distribution and prevalence of Mycoplasma hyopneumoniae positive sows by PCR regarding different parity orders within the three herds.

\begin{tabular}{|c|c|c|c|}
\hline Herds $^{*}$ & Parity & Sampled sows (n) & Positive/tested (\%) \\
\hline $\mathrm{A}$ & 1 & 33 & $2 / 33(6.06)$ \\
\hline \multirow{6}{*}{ B } & 2 & 7 & $0 / 37(0.0)$ \\
\hline & 3 & 11 & $1 / 37(2.7)$ \\
\hline & 4 & 9 & $2 / 37(5.4)$ \\
\hline & 5 & 5 & $1 / 37(2.7)$ \\
\hline & 6 & 5 & $0 / 37(0.0)$ \\
\hline & Total & 37 & 4/37 (10.8) \\
\hline \multirow{7}{*}{$\mathrm{C}$} & 1 & 8 & $0 / 34(0.0)$ \\
\hline & 2 & 7 & $1 / 34(2.9)$ \\
\hline & 3 & 7 & $1 / 34(2.9)$ \\
\hline & 4 & 4 & $0 / 34(0.0)$ \\
\hline & 5 & 6 & $1 / 34(2.9)$ \\
\hline & 6 & 2 & $0 / 34(0.0)$ \\
\hline & Total & 34 & $3 / 34(8.8)$ \\
\hline
\end{tabular}

*Herd A represents the pigs born in farrowing unit A (herd composed only by gilts and primiparous sows); herd B represents the pigs born in farrowing unit B (parity order $\geq 2$ sows); herd $C$ represents the pigs born in farrowing unit $C$ (herd composed by gilts and older parity order sows).

such as herniations. A total of 48, 61 and 63 lungs were assessed in herds $\mathrm{A}, \mathrm{B}$ and $\mathrm{C}$, respectively. Presence and severity of enzootic pneumonia-like lung lesions were significantly different among herds (Table 2). In herd B, pneumonia prevalence and severity were significantly higher $(\mathrm{P}<0.05)$ when compared to herds A and C, where $100 \%$ of lungs presented pneumonic lesions covering an average of $26.2 \%$ of the lungs surface. In herd A, $66.7 \%$ of lungs presented pneumonic lesions covering an average of $8.7 \%$ of the lungs surface. In herd C, $15.9 \%$ of lungs presented pneumonic lesions with an average lesion extension of $1.1 \%$. Additionally, a total of $5.8 \%$ of pigs which were $M$. hyopneumoniae positive by PCR at weaning presented lung lesions at slaughter age within all herds included in the study. A proportion of $54.1 \%$ of pigs were not detected positive for $M$. hyopneumoniae by PCR at weaning and showed pneumonic lesions at slaughter (data not shown).

\section{DISCUSSION}

Mycoplasma hyopneumoniae was detected in all farrowing units at low prevalence in sows prior to farrowing, ranging from $6.06 \%$ to $10.81 \%$. Even though studies suggested that prevalence decreases as sow parity order increased (CALSAMIGLIA \& PIJOAN, 2000), we could not find such relationship in sows prior to farrowing. Interestingly, replacement females (PO1 in herd $\mathrm{C}$ and $\mathrm{PO} 2$ in herd $\mathrm{B}$ ) were not detected positive prior to the first farrowing after being transferred to the farrowing units included in this study. However, these findings should be interpreted carefully due to the low number of sows sampled in each parity order category, which might have underestimated the true prevalence of positive sows. On the other hand, in farrowing unit A, the higher number of females sampled in the same parity order probably increased the probability of detection. Other studies revealed varying results regarding sow prevalence at farrowing. CALSAMIGLIA \& PIJOAN (2000) detected a prevalence of $25 \%$ of sows positive for $M$. hyopneumoniae at farrowing regardless parity order. PIETERS et al. (2014) observed that prevalence of M. hyopneumoniae detection in different parity order sows at weaning ranged from $0-48 \%$, and TAKEUTI et al. (2017b) found a $0-15.7 \%$ prevalence in self-replacement gilts prior to farrowing or during the lactation period.

In this context, parity segregation could be used as an alternative to control $M$. hyopneumoniae infections. It is speculated that segregating gilts from multiparous sows until their first farrowing would provide enough time for gilts to become infected, recover and stop shedding $M$. hyopneumoniae before being transferred to the multiparous sow herd (MAES et al., 2008). However, this pattern was not observed in our study. It was expected that the detection of $M$. 


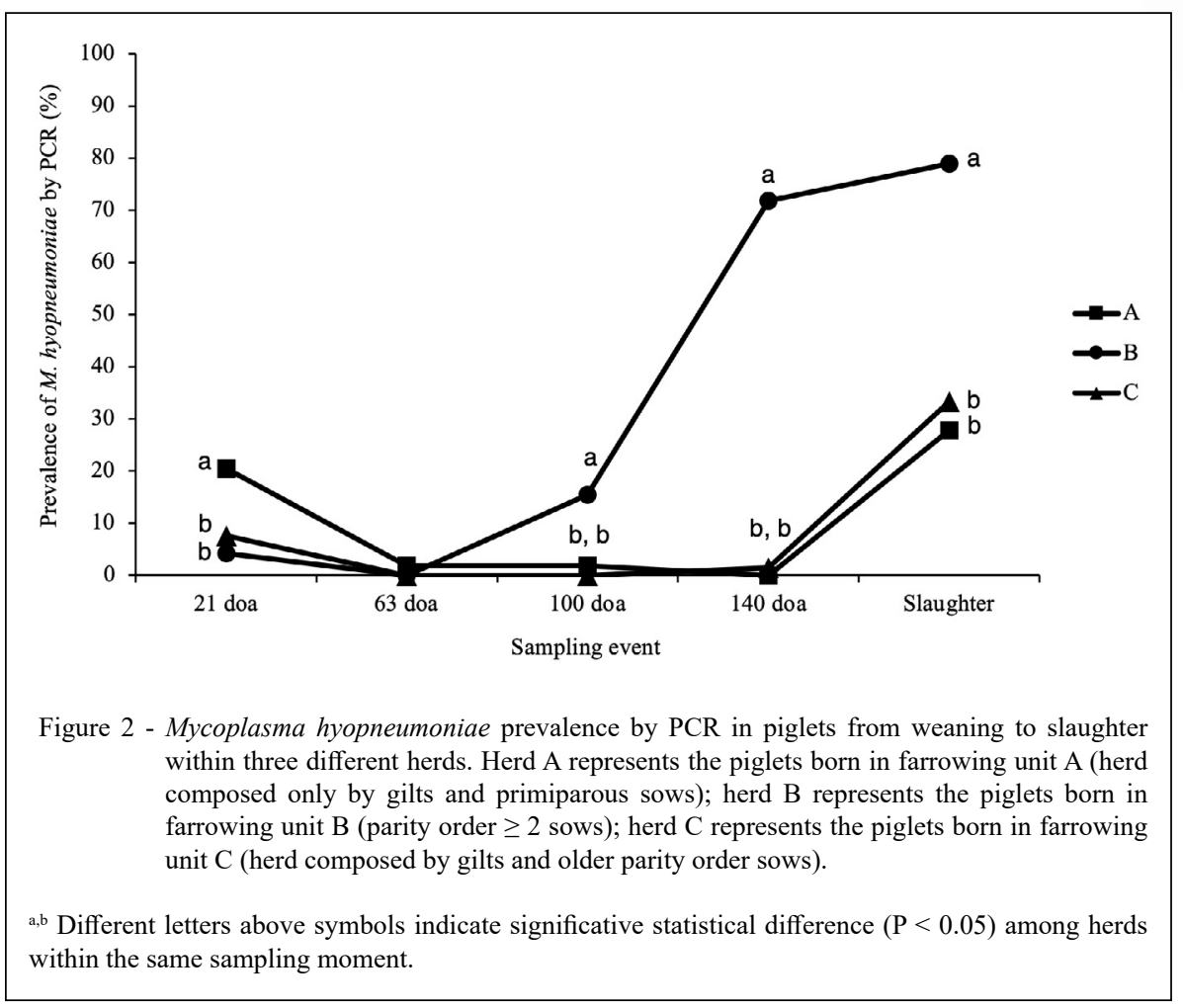

hyopneumoniae in sows would be higher in herd A (PO1) and prevalence would be lower in herd B ( $\geq$ PO2). The lack of a proper acclimation management is one factor that might have contributed to these results. It is hypothesized that the absence of a prior controlled exposure of young gilts could have induced the presence of negative subpopulations of sows over time making them susceptible to future infections regardless the parity order. In fact, second parity sows in farm B might have been in the same health status as first parity sows due to an ineffective acclimation management, where no sows were detected positive, which might have superimposed the benefits of removing first parity sows in this farrowing unit. $M$. hyopneumoniae negative subpopulations were previously described by TAKEUTI et al. (2017a), where $18.2 \%$ of naturally infected gilts did not become positive at any sampling moment from 0 to 358 doa. In our study, sows were sampled once in a cross-sectional pattern, which might have limited the understanding of the infection dynamics in these farrowing units. Although our results suggested no effect of segregating gilts on $M$. hyopneumoniae colonization, assumptions regarding infection dynamics in sows should be taken carefully. Nevertheless, even in parity segregated systems early exposure to pathogens is critical. An inefficient pathogen exposure allows the introduction of naïve animals and poses a risk of infection to the recipient herd (MOORE, 2005).

It was already reported that a single tulathromycin administration at 112 days of gestation reduced sow shedding and the number of positive sows at farrowing and weaning (HOLST et al., 2013). Even though a single tulathromycin injection was administrated in all gilts of this study at 160 doa, it is unlikely that it had an effect on the detection of $M$. hyopneumoniae in gilts at farrowing, since sampling was performed at least 160 days later.

Other factors affecting sow colonization could be related to replacement rates and movement of sows. Parity segregation increases the number of movements of sows, increasing the risk of contamination (MOORE, 2005). Moreover, high replacement rates have been described to increase occurrence of enzootic pneumonia (NATHUES et al., 2013) and seroprevalence for M. hyopneumoniae in sows (FANO \& PIJOAN, 2006). Since farrowing unit A was composed only by gilts, these animals were housed for a shorter period when compared to conventional herds, and replacement rates reach $100 \%$ over the year. Also, females were constantly 
Table 2 - Prevalence and extension of pneumonic lesions in pigs within three different herds.

\begin{tabular}{|c|c|c|c|c|c|c|c|c|}
\hline & & & Frequency of pneumonic lesions (\%) & ------- & ig lesic & tension & --------- & \\
\hline Herd* & $\mathrm{n}$ & Slaughter age (days) & & Mean & Min & Max & SD & Score \\
\hline A & 48 & 184 & $66.7^{\mathrm{b}}$ & $8.9^{\mathrm{b}}$ & 0.0 & $49.0^{b}$ & \pm 11.6 & 1.17 \\
\hline B & 61 & 177 & $100.0^{\mathrm{a}}$ & $26.2^{\mathrm{a}}$ & 1.5 & $60.7^{\mathrm{a}}$ & \pm 16.0 & 2.90 \\
\hline $\mathrm{C}$ & 63 & 174 & $15.9^{c}$ & $1.1^{\mathrm{c}}$ & 0.0 & $25.0^{\mathrm{c}}$ & \pm 3.8 & 0.21 \\
\hline
\end{tabular}

Min: minimum, Max: maximum, SD: Standard deviation.

a,b,c Different superscript letters within a column indicate significative statistical difference $(\mathrm{P}<0.05)$.

${ }^{*}$ Herd A represents the pigs born in farrowing unit A (herd composed only by gilts and primiparous sows); herd B represents the pigs born in farrowing unit $\mathrm{B}$ (parity order $\geq 2$ sows); herd $\mathrm{C}$ represents the pigs born in farrowing unit $\mathrm{C}$ (herd composed by gilts and older parity order sows).

introduced and removed from this herd on a weekly basis. On the other hand, in farrowing units B and $\mathrm{C}$, replacement rates were similar to those usually practiced in conventional farms.

Low to moderate detection of $M$. hyopneumoniae by PCR was observed in piglets at weaning in all herds, ranging from $4.23 \%$ to $20.37 \%$. Other studies revealed varying results in piglets at this age. Low prevalence of positive piglets has been reported, ranging from 1.5 to $3.8 \%$ by nestedPCR in nasal swabs (SIBILA et al., 2007). High detection of positive piglets was observed, ranging from $36.7 \%$ (VILLARREAL et al., 2010) to $51.28 \%$ (FANO et al., 2007) in nasal swabs by nested PCR. A higher detection of positive piglets was observed in herd A. These findings are in accordance with those reported by FANO et al. (2006) where prevalence of positive piglets was higher in piglets born to young sows, although some studies did not observe effect of dam parity order on piglet prevalence at weaning (CALSAMIGLIA \& PIJOAN, 2000; PIETERS et al., 2014). It is assumed that prevalence at weaning is mainly explained by vertical transmission during the lactation period (FANO et al., 2006). Sow-topiglet transmission was observed in $3.7 \%$ of piglets in our study. It was documented that sow PCR status for M. hyopneumoniae was positively correlated to piglet PCR status at weaning (PIETERS et al., 2014); although, some studies did not detect transmission from sow to piglet by real-time PCR using laryngeal swabs (TAKEUTI et al., 2017b).

Prevalence of positive piglets for $M$. hyopneumoniae decreased to $0.0-1.85 \%$ at the end of the nursery period (63 doa) in all herds. In herds $\mathrm{A}$ and $\mathrm{C}$ it remained at low levels from 100 doa until slaughter when it reached $27.78 \%$ and $33.33 \%$ respectively. However, in herd B the prevalence was significantly higher at 100 doa $(15.49 \%)$, at 140 doa $(71.83 \%)$ and at slaughter age $(78.87 \%)$ when compared to pigs from herds $\mathrm{A}$ and $\mathrm{C}$. The low prevalence reported throughout the study in herds A and $\mathrm{C}$ could be explained by the low transmission rate (MEYNS et al., 2004) and the persistence of infection for long periods (PIETERS et al., 2009). Another factor that might have reduced prevalence of positive piglets born in farrowing unit $\mathrm{A}$ is the vaccination of gilts at 95 days of gestation. It has been reported that vaccination of sows during gestation reduces piglet colonization at weaning and occurrence of lung lesions (ARSENAKIS et al., 2019). The increased prevalence in herd $\mathrm{B}$ might be due to differences in health challenges among the herds of this study. Herd sizes were larger in all units of herd B (farrowing unit, nursery and finishing unit), which may be a risk factor to the spread of respiratory pathogens (MAES et al., 2000). In fact, herd sizes were approximately three times larger in herd B when compared to herds A and C. Also, the presence of different $M$. hyopneumoniae variants might have increased disease transmission and severity in herd $\mathrm{B}$, since it is already known that the prevalence and severity of lung lesions are related to the number of $M$. hyopneumoniae variants (MICHIELS et al., 2017).

At slaughter, occurrence of enzootic pneumonia like lung lesions ranged from 15.9 to $100 \%$ and the average lung lesion extension varied from 1.14 to $26.25 \%$. Pigs from herd B presented the highest prevalence and most severe lung lesions when compared to pigs from herds $\mathrm{A}$ and $\mathrm{C}$, which might be explained by the high prevalence of $M$. hyopneumoniae detection by PCR in the finishing phase, on the contrary of the findings reported by MOORE (2005), where a threefold reduction of lung lesions was observed in the progeny born to the 
farrowing unit with no gilts. Prevalence and severity of pneumonic lesions have been reported to be predicted by piglet prevalence by PCR at weaning (FANO et al., 2007). However, in the present study only $5.8 \%$ of piglets that were positive for $M$. hyopneumoniae by PCR at weaning presented lung lesions at slaughter. The majority $(54.1 \%)$ of piglets was negative at weaning and presented lung lesions, which could be explained by predominance of infections occurring during the finishing period, which often occurs in multisite production systems (SIBILA et al., 2004; GIACOMINI et al., 2016).

It must be considered that sample types were different during the study. Currently it is known that the most sensitive sample types in vivo are obtained from the lower respiratory tract (trachea and bronchi) (SPONHEIM et al., 2020), which were collected in sows and pigs from 63 to 140 doa in our study. However, nasal swabs were used in piglets at 21 doa due to the difficulty of collecting deeper samples at this age, which may have overestimated the number of colonized piglets, since the bacterium attaches ciliated epithelial cells present in the low respiratory tract, such as trachea, bronchi and bronchioles (CHAE et al., 2020). In addition, lung samples showed an increase in the detection of positive pigs by PCR.

\section{CONCLUSION}

Based in our results, parity segregation alone was not effective in controlling $M$. hyopneumoniae infection and lung lesions at slaughter, since detection of positive piglets and occurrence of pneumonic lesions in the herd with no gilts were higher than the herd composed only by gilts and the conventional herd. Some factors might have influenced these results, such as differences in herd sizes, health status and vaccination protocols. However, it is hypothesized that the lack of a proper acclimation management in gilts might have contributed to the presence of naïve primiparous sows being introduced to the recipient herd. All these factors must be considered when adopting parity segregation as they might overlap the benefits of removing first parity sows from a herd.

\section{ACKNOWLEDGEMENTS}

This project was funded by Coordenação de Aperfeiçoamento de Pessoal de Nível Superior (CAPES) and Fundo de Desenvolvimento e Defesa Sanitária Animal (FUNDESA).The authors acknowledge Master Agroindustry (Videira, Santa Catarina, Brazil) for providing the farms and the assistance of farms employees.

\section{DECLARATION INTEREST \\ OF CONFLICT}

OF

The authors declare no conflict of interest. The founding sponsors had no role in the design of the study; in the collection, analyses, or interpretation of data; in the writing of the manuscript, and in the decision to publish the results.

\section{AUTHORS' CONTRIBUTIONS}

All authors contributed equally to the conception and writing of the manuscript. All authors critically reviewed the manuscript and approved the final version.

\section{BIOETHICS AND BIOSSECURITY COMMITTEE APPROVAL}

Study procedures were conducted under the approval of the Research Committee of the Universidade Federal do Rio Grande do Sul, Brazil (protocol number 36730).

\section{REFERENCES}

ARSENAKIS, I. et al. Effects of pre-farrowing sow vaccination against Mycoplasma hyopneumoniae on offspring colonisation and lung lesions. Veterinary Record, v.184, n.7, p.222-222, 2019. Available from: <https://bvajournals.onlinelibrary.wiley.com/doi/ full/10.1136/vr.104972>. Accessed: Sep. 19, 2020. doi: 10.1136/ vr. 104972 .

BREAN, M. et al. Influence of parity of birth and suckled sows on piglet nasal mucosal colonization with Haemophilus parasuis. The Canadian Veterinary Journal, v.57, n.12, p.1281, 2016. Available from: <https://www.ncbi.nlm.nih.gov/pmc/articles/ PMC5109632/>. Accessed: Mar. 13, 2020. PMID:27928176.

CALSAMIGLIA, M.; PIJOAN, C. Colonisation state and colostral immunity to Mycoplasma hyopneumoniae of different parity sows. The Veterinary Record, v.146, n.18, p.530-532, 2000. Available from: <https://bvajournals.onlinelibrary.wiley.com/ doi/abs/10.1136/vr.146.18.530>. Accessed: Mar. 10, 2020. doi: 10.1136/vr.146.18.530.

CHAE, C. et al. Diagnosis of Mycoplasma hyopneumoniae infection and associated diseases. In: MAES, D. et al. Mycoplasmas in Swine. Leuven: Acco, 2020. p.147-161.

CHRISTENSEN, G. et al. Diseases of the respiratory system. In: STRAW, B.E. et al. Diseases of Swine. Ames: Iowa State University Press, 1999. p. 913-940.

ENGBLOM, L. et al. Sow removal in Swedish commercial herds. Livestock science, v.106, n.1, p.76-86, 2007. Available from: $\quad<$ https://www.sciencedirect.com/science/article/abs/pii/ S1871141306002472>. Accessed: May, 17, 2020. doi: 10.1016/j. livsci.2006.07.002.

FANO, E. et al. Assessment of the effect of sow parity on the prevalence of Mycoplasma hyopneumoniae in piglets at weaning. In: 19TH INTERNATIONAL PIG VETERINARY SOCIETY CONGRESS, 2006, Copenhagen, Denmark. Proceedings... Copenhagen: Scientific Committee of the $19^{\text {th }}$ IPVS Congress, 2006. Accessed: Feb. 18, 2020. 
FANO, E. et al. Dynamics and persistence of Mycoplasma hyopneumoniae infection in pigs. Canadian Journal of Veterinary Research, v.69, n.3, p.223, 2005. Available from: <https://www. ncbi.nlm.nih.gov/pmc/articles/PMC1176302/>. Accessed: Mar. 13, 2020. PMID:16187553.

FANO, E. et al. Effect of Mycoplasma hyopneumoniae colonization at weaning on disease severity in growing pigs. Canadian Journal of Veterinary Research, v.71, n.3, p.195, 2007. Available from: $<$ https://www.ncbi.nlm.nih.gov/pmc/articles/PMC1899865/>. Accessed: Mar. 20, 2020. PMID: 17695594.

FANO, E.; PIJOAN, C. Assessing the Mycoplasma hyopneumoniae infection pattern in a sow herd following an increase in the replacement rate. In: ALLEN D. LEMAN SWINE CONFERENCE, 2006, St. Paul, Minesota. Proceedings... St. Paul: University of Minnesota College of Veterinary Medicine, 2006. Accessed: Feb. $18,2020$.

GADD, J. Parity Segregation. In: Modern Pig Production Technology. Nottingham: Nottingham University Press, 2011. p. $467-474$.

GIACOMINI, E. et al. Dynamics of Mycoplasma hyopneumoniae seroconversion and infection in pigs in the three main production systems. Veterinary Research Communications, v.40, n.2, p.81-88, 2016. Available from: <https://link.springer.com/ article/10.1007/s11259-016-9657-6>. Accessed: Sep. 7, 2020. doi: $10.1007 / \mathrm{s} 11259-016-9657-6$

HOLST, S. et al. Effect of pre-farrow administration of tulathromycin injectable solution on Mycoplasma hyopneumoniae prevalence in suckling pigs at birth and weaning. In: 44th Annual Meeting of the American Association of Swine Veterinarians, San Diego, California. Proceedings... Perry: American Association of Swine Veterinarians, 2013. p. 0-5. Accessed: Oct. 10, 2020.

MADEC, F.; KOBISCH, M. Bilan lésionnel des poumons de porcs charcutiers à l'abattoir. Journées de la Recherche Porcine, v.14, n.8, 1982. Available from: <http://www.journees-rechercheporcine.com/texte/1982/82txtPatho/P8204.pdf $>$. Accessed: Jun. 8, 2020.

MAES, D. et al. Control of Mycoplasma hyopneumoniae infections in pigs. Veterinary Microbiology, v.126, n.4, p.297-309, 2008. Available from: <https:/www.sciencedirect.com/science/article/ pii/S0378113507004506>. Accessed: Mar. 8, 2020. doi: 10.1016/j. vetmic.2007.09.008

MAES, D. et al. Herd factors associated with the seroprevalences of four major respiratory pathogens in slaughter pigs from farrowto-finish pig herds. Veterinary Research, v.31, n.3, p.313-327, 2000. Available from: <https://www.vetres.org/articles/vetres/ abs/2000/03/v0303/v0303.html>. Accessed: Jun. 8, 2020. doi: 10.1051/vetres:2000122.

MAES, D. et al. Update on Mycoplasma hyopneumoniae infections in pigs: knowledge gaps for improved disease control. Transboundary and Emerging Diseases, v.65, p.110-124, 2018. Available from: <https://onlinelibrary.wiley.com/doi/abs/10.1111/ tbed.12677>. Accessed: Jun. 14, 2020. doi: 10.1111/tbed.12677.

MEYNS, T. et al. Quantification of the spread of Mycoplasma hyopneumoniae in nursery pigs using transmission experiments. Preventive Veterinary Medicine, v.66, n.1-4, p.265-275, 2004 Available from: <https://www.sciencedirect.com/science/article/
abs/pii/S0167587704001989>. Accessed: Sep. 14, 2020. doi: 10.1016/j.prevetmed.2004.10.001

MICHIELS, A. et al. Impact of diversity of Mycoplasma hyopneumoniae strains on lung lesions in slaughter pigs. Veterinary Research, v.48, n.1, p.1-14, 2017. Available from: $<$ https://veterinaryresearch.biomedcentral.com/articles/10.1186/ s 13567-016-0408-z\#: : :text=hyopneumoniae \%20strains $\% 20$ had $\% 20 \mathrm{a} \% 20$ higher,respiratory $\% 20$ health $\% 20$ of $\% 20$ the $\% 20$ pigs $>$. Accessed: Oct. 10, 2020. doi: 10.1186/s13567-016-0408-z.

MOORE, C. Parity Segregation. In: 5th London Swine Conference, London, Ontario. Proceedings... London: London Swine Conference, 2005. p.61-67. Accessed: Feb.18, 2020.

NATHUES, H. et al. Herd specific risk factors for Mycoplasma hyopneumoniae infections in suckling pigs at the age of weaning. Acta Veterinaria Scandinavica, v.55, n.1, p.1-13, 2013. Available from: $<$ https://link.springer.com/article/10.1186/1751-0147-55-30>. Accessed: Mar. 14, 2020. doi: 10.1186/1751-0147-55-30.

PIETERS, M. et al. An assessment of the duration of Mycoplasma hyopneumoniae infection in an experimentally infected population of pigs. Veterinary Microbiology, v.134, n.3-4, p.261-266, 2009. Available from: <https://www.sciencedirect.com/science/ article/pii/S0378113508003507>. Accessed: Oct. 10, 2020. doi: 10.1016/j.vetmic.2008.08.016.

PIETERS, M. et al. Intra-farm risk factors for Mycoplasma hyopneumoniae colonization at weaning age. Veterinary Microbiology, v.172, n.3-4, p.575-580, 2014. Available from: $<$ https:// www.sciencedirect.com/science/article/pii/S0378113514002739>. Accessed: Mar. 10, 2020. doi: 10.1016/j.vetmic.2014.05.027.

PIETERS, M.; FANO, E. Mycoplasma hyopneumoniae management in gilts. Veterinary Record, v.178, n.5, p.122123, 2016. Available from: <https://pubmed.ncbi.nlm.nih. gov/26823313/>. Accessed: Mar. 14, 2020. doi: 10.1136/vr.i481.

SIBILA, M. et al. Current perspectives on the diagnosis and epidemiology of Mycoplasma hyopneumoniae infection. The Veterinary Journal, v.181, n.3, p.221-231, 2009. Available from: $<$ https://www.sciencedirect.com/science/article/abs/pii/ S1090023308000816>. Accessed: Sep. 7, 2020. doi: 10.1016/j. tvj1.2008.02.020.

SIBILA, M. et al. Dynamics of Mycoplasma hyopneumoniae infection in 12 farms with different production systems. Canadian Journal of Veterinary Research, v.68, n.1, p.12, 2004. Available from: <https://www.ncbi.nlm.nih.gov/pmc/articles/ PMC1142124/>. Accessed: May, 17, 2020. PMID:14979430.

SIBILA, M. et al. Exploratory field study on Mycoplasma hyopneumoniae infection in suckling pigs. Veterinary Microbiology, v.121, n.3-4, p.352-356, 2007. Available from: $\quad<$ https://www.sciencedirect.com/science/article/pii/ S0378113506005104>. Accessed: Mar. 13, 2020. doi: 10.1016/j. vetmic.2006.12.028.

SPONHEIM, A. et al. Comparison of the sensitivity of laryngeal swabs and deep tracheal catheters for detection of Mycoplasma hyopneumoniae in experimentally and naturally infected pigs early and late after infection. Veterinary Microbiology, v.241, p.108500, 2020. Available from: <https://www.sciencedirect.com/ science/article/pii/S0378113519307862>. Accessed: Nov. 15, 2020. doi: 10.1016/j.vetmic.2019.108500. 
TAKEUTI, K. L. et al. Detection of Mycoplasma hyopneumoniae in naturally infected gilts over time. Veterinary Microbiology, v.203, p.215-220, 2017a. Available from: <https://www.sciencedirect. com/science/article/pii/S0378113517301785> . Accessed: Mar. 20, 2020. doi: 10.1016/j.vetmic.2017.03.025.

TAKEUTI, K.L. et al. Infection dynamics and genetic variability of Mycoplasma hyopneumoniae in self-replacement gilts. Veterinary Microbiology, v.208, p.18-24, 2017b. Available from: $\quad<$ https://www.sciencedirect.com/science/article/pii/ S0378113517303905>. Accessed: Mar. 20, 2020. doi: 10.1016/j. vetmic.2017.07.007.
VILLARREAL, I. et al. Early Mycoplasma hyopneumoniae infections in European suckling pigs in herds with respiratory problems: detection rate and risk factors. Veterinarni Medicina, v.55, n.7, p.318-324, 2010. Available from: $<$ https://biblio.ugent. be/publication/1113583>. Accessed: Oct. 10, 2020.

VRANCKX, K. et al. Multiple-locus variable-number tandemrepeat analysis is a suitable tool for differentiation of Mycoplasma hyopneumoniae strains without cultivation. Journal of Clinical Microbiology, v.49, n.5, p.2020-2023, 2011. Available from: $<$ https://jcm.asm.org/content/49/5/2020.short>. Accessed: Nov. 15, 2020. doi: 10.1128/JCM.00125-11. 